\title{
ROLE OF HEAVY METAL RESISTANT BACTERIA FOR BIOREMEDIATION OF POLLUTED ENVIRONMENT
}

\author{
Fariha Zakria Rizvi \\ Department of Microbiology and Molecular Genetics, University of the Punjab, Quaid-e-Azam Campus, Lahore-54590, Pakistan. \\ Muhammad Faisal* \\ Department of Microbiology and Molecular Genetics, University of the Punjab, Quaid-e-Azam Campus, Lahore-54590, Pakistan. \\ *Corresponding author \\ Department of Microbiology and Molecular Genetics, University of the Punjab, Quaid-e-Azam Campus, Lahore-54590, Pakistan. Telephone, \\ 924235952811; Email, mohdfaysal@yahoo.com
}

\begin{abstract}
Bioremediation refers to the use of microorganisms to reduce or eliminate contaminants from water and soil. In the current research, different bacterial strains were screened for their chromate and arsenate reduction potential. For the removal of arsenic, eight arsenic resistant bacterial strains AsK03, AsK04, AsK06, AsK07, AsK08, AsK09, AsK15 and AsK18 and for chromium removal, eight chromium resistant bacterial strains CrK02, CrK08, CrK12, CrK14, CrK16, CrK19, CrK20 and CrK21 were isolated and selected, respectively, from several contaminated soil and water samples taken from tanneries located in Kasur. Resistance to chromium and arsenic was shown by all the strains on nutrient agar at preliminary concentration of $500 \mu \mathrm{g} \mathrm{ml}^{-1}$. The maximum tolerable concentration (MTC) of these isolates was also studied. It was found that for arsenic resistance, two strains AsK04 and AsK09 had highest MTC of $100 \mathrm{mg} \mathrm{ml}^{-1}$, AsK18 had $75 \mathrm{mg} \mathrm{ml}^{-1}$, AsK03, AsK06 and AsK15 had $50 \mathrm{mg} \mathrm{ml}^{-1}$ and AsK07 and AsK08 had $45 \mathrm{mg} \mathrm{ml}^{-1}$ of $\mathrm{Na}_{2} \mathrm{HAsO}_{4}$ concentration. Similarly, chromium resistant strains were also checked for their MTC against $\mathrm{K}_{2} \mathrm{CrO}_{4}$. Here MTC of CrK16 and CrK19 were highest (75 mg ml-1), CrK08 and CrK12 were $50 \mathrm{mg} \mathrm{ml}^{-1}$, CrK02 and CrK20 were $25 \mathrm{mg} \mathrm{ml}^{-1}$, CrK14 and CrK21 had least MTC of $7.5 \mathrm{mg} \mathrm{ml}^{-1}$. Fifteen of the bacterial strains were genetically identified by sequencing of 16S rRNA gene. BLAST analysis revealed that the seven strains are homologous to genus Bacillus.
\end{abstract}

Key words: Bioremediation, chromium, arsenic, Bacillus, Kasur

\section{Introduction}

During the last century, toxic metals contamination has posed a serious risk to the human health and the environment. Contaminated food and water exposure or ingestion leads to metal poisoning (Tamas et al., 2005). Heavy metal may be described as "a chemical element that possesses a specific gravity (a measure of density) at least five times that of water" (Thivierge, 2005). Microbial systems including algae, bacteria and fungus have recently been used successfully as adsorbent agents for heavy metals removal (Terres, 1998; Munoz, 2006a, 2006b, Pena-Castro, 2004). In metal contaminated conditions, microbial communities respond to toxic heavy metal concentrations and 
become metal tolerant (Prasenjit, 2005). Chromium discharged from leather tanning, alloy preparation and electroplating are the most common heavy metals pollutants (Ozdemir, 2005). Cr (VI) spontaneously reacts with the intracellular (glutathione and ascorbate) reducing agents under the normal physiological conditions to produce the short term intermediates $\mathrm{Cr}$ (V) and/or Cr (IV), free radicals and the end products Cr (III) (Costa, 2003; Xu et al., 2004; 2005). Numerous cellular enzymes with various metabolic functions reduce chromate by one-electron transfer. This produces the most unstable radical $\mathrm{Cr}(\mathrm{V})$, which reverted to $\mathrm{Cr}(\mathrm{VI})$ via oxidation in redox cycles, by providing their electron to molecular oxygen and then producing reactive oxygen species (ROS) (Ackerley, 2004; 2005). Reduce of $\mathrm{Cr}$ (VI) to Cr (III) can be done by bacteria (Park et al., 2000; 2002; Ackerley et al., 2004), however, many changes at enzyme and cellular levels are required in order to make bacteria effective agent for bioremediation of chromate. Treatment of hexavalent chromium in wastewater, much work has been done to minimize its toxic effects on the ecosystem. Conventional $\mathrm{CrO}_{4}{ }^{2-}$ removal methods include, ion exchange, adsorption on activated coal, ash, alum, and kaolinite, and chemical reduction followed by precipitation (Camargo, 2003). Although these methods are very effective and are used in the treatment of wastewater, but there are some problems with these methods which are unavoidable. When heavy metals are concentrated between 1 and $100 \mathrm{mgl}^{-1}$, treatment and materials are more expensive (Xu et al., 2005). Some treatments demonstrate low selectivity to compete for alkaline-earth-metal absorption (Xu et al., 2005). Phosphate transporters is used to uptake the Arsenate (As (V)), whereas As (III) is taken up by aquaglyceroporins (Fps1p in yeast, AQP7 and AQP9 in mammals and GlpF in E. coli), and hexose permeases (GLUT1 and GLUT4 in mammals, and HXT9, HXT7, HXT5, HXT4, HXT3 or HXT1 in yeast). Arsenate to arsenite reduction in both E. coli and S. cerevisiae is carried out by the bacterial ArsC or yeast Acr2p enzymes, respectively. Glutathione and glutaredoxine are the source of possible reduction in both organisms. Whereas proteins that are responsible for arsenate absorption and reduction are not yet known in mammals. Arsenite is extracted by ArsB alone or by ArsAB ATPase from cells in E. coli. In yeast, As (GS)3 is transported to vacuole by arsenite efflux protein Acr3p (present in plasma membrane), and Ycflp (a member of the MRP family of the ABC superfamily of drug resistance pumps). In mammals, As (GS)3 is removed from the cells by Mrp2 which is an isoform of Mrp (adopted from Rosen, 2009).

ArsD has recently been identified as a metallochaperone or arsenite-binding protein (Lin, 2006) that sequesters and delivers intracellular arsenite to ArsA before it is pumped out of the cell by the action of the ArsAB (membrane efflux pump) (Rawlings, 2008). The ability of microorganisms to remove heavy metal from the environment and transform it from a more toxic form to a less toxic one, can be used for the bioremediation of sites highly contaminated with heavy metals like arsenic and chromium, such as those that occur in Muzzafargarh, Kasur, Karachi, Sheikhupura, Sialkot and other industrial cities of Pakistan. In Pakistan, industrial workplaces, including those of tanneries, also provide new enrichment environments for the natural selection of novel bacterial strains of metal resistance and remediation because regulatory control over industrial emissions is restricted. 


\section{Material and Method}

Different soil samples (KS-1, KS-2, KS-3, KS-4, KS-5) and a wastewater sample (KW-6) were collected from tanneries of Kasur in disposable sterilized bags and labelled accordingly. Temperature and $\mathrm{pH}$ were observed on the site, with samples being moved to the laboratory immediately for further treatment.

\section{Isolation of Strains}

Bacteria were isolated on L-agar medium. For the isolation of metal resistant bacteria from the sample, Lagar medium was supplemented with metallic salt concentration of $500 \mu \mathrm{g} \mathrm{ml}^{-1}$. For this purpose a stock solution of $10^{5} \mathrm{~g} \mathrm{ml}^{-1}$ (10\%) was prepared (Salt used for preparing stock solution for arsenic was $\mathrm{Na}_{2} \mathrm{HAsO}_{4} .7 \mathrm{H}_{2} \mathrm{O}$ and for chromium was $\mathrm{K}_{2} \mathrm{CrO}_{4}$ ). The required concentration of the metallic salt was added to agar medium when it was cool enough, but had not yet solidified. Samples were diluted up to $10^{-2}$ dilutions in autoclaved water and then spreaded on already prepared L-agar plates supplemented with respective concentration of arsenic and chromium $\left(500 \mu \mathrm{g} \mathrm{ml}^{-1}\right)$. The plates were incubated for 24 to 48 hours at $37^{\circ} \mathrm{C}$. The obtained colonies were selected and purified by several round squeezing on L-agar plates, supplemented with $500 \mathrm{~g} \mathrm{~m} \mathrm{ml}^{-1}$ arsenic and chromium. Higher levels of respective metallic salt were tested for resistant strains. From the colonies grown, eight arsenic resistant strains and eight chromium resistant strains were chosen. Isolates were further characterized based on morphology, biochemical tests, physiological parameters and genetic identification.

\section{Results}

\section{Heavy Metal Resistance Profile of Arsenic and Chromium Resistant Bacteria}

Six heavy metals, $\mathrm{MnSO}_{4}, \mathrm{ZnSO}_{4}, \mathrm{~K}_{2} \mathrm{CrO}_{4}, \mathrm{CuSO} 4, \mathrm{CdCl}_{2}, \mathrm{HgCl}_{2}$ and/or $\mathrm{Na}_{2} \mathrm{HAsO}_{4}$ were used, to check the heavy metal resistance profile of the bacteria, at concentrations of $250 \mu \mathrm{g} \mathrm{ml}^{-1}, 500 \mu \mathrm{g} \mathrm{ml}^{-1}, 750 \mu \mathrm{g} \mathrm{ml}^{-1}$ and $1000 \mu \mathrm{g}$ $\mathrm{ml}^{-1}$. $\mathrm{MnSO}_{4}$ and $\mathrm{K}_{2} \mathrm{CrO}_{4} / \mathrm{Na}_{2} \mathrm{HAsO}_{4}$ were also checked at high concentrations that were $1250 \mu \mathrm{g} \mathrm{ml}^{-1}, 1500 \mu \mathrm{g} \mathrm{ml}^{-1}$, $1750 \mu \mathrm{g} \mathrm{ml}^{-1}$ and $2000 \mathrm{\mu g} \mathrm{ml}^{-1}$ since all the strains managed to resist both these metals to a higher level. None of the arsenic resistant strain could resist $\mathrm{HgCl}_{2}$ even at $250 \mu \mathrm{g} \mathrm{ml}^{-1}$. However, chromium resistant $\mathrm{CrK02}$ and Staphylococcus pasteuri-CrK14 showed resistance up to $250 \mathrm{~g} \mathrm{ml}^{-1}$, Cellulosimicrobium cellulans-CrK16 resisted up to $500 \mu \mathrm{g} \mathrm{ml}^{-1}$, CrK12 and Bacillus cereus-CrK20 resisted up to $750 \mu \mathrm{g} \mathrm{ml}^{-1}$, however, Bacillus pumilus-CrK08, Exiguobacterium-CrK19 and Bacillus licheniformis-CrK21 were found to be sensitive to $\mathrm{HgCl}_{2}$. All the strains were sensitive to $\mathrm{CdCl}_{2}$ except AsK06 and Bacillus pumilus-CrK08 that had shown resistance to $250 \mu \mathrm{g} \mathrm{ml}{ }^{-1}$, Cellulosimicrobium cellulans-CrK16 and Bacillus cereus-CrK20 that had resistant to $750 \mu \mathrm{g} \mathrm{ml}^{-1}$ and $\mathrm{CrK} 12$ that resisted up to $1000 \mu \mathrm{g} \mathrm{ml}^{-1}$. Bacillus subtilus-AsK18, CrK02, Bacillus pumilus-CrK08, Staphylococcus pasteuriCrK14 and Exiguobacterium-CrK19 exhibited resistance to $\mathrm{ZnSO}_{4}$ at a concentration of $250 \mu \mathrm{g} \mathrm{ml}^{-1}$, however AsK06, Bacillus cereus-CrK20 displayed resistance to it at a concentration of $500 \mathrm{~g} \mathrm{ml}^{-1}$ and $\mathrm{CrK} 12$ and Cellulosimicrobium cellulans-CrK16 were found to be resistant up to $750 \mu \mathrm{g} \mathrm{ml}^{-1}$, but all other strains were found to be sensitive to $\mathrm{ZnSO}_{4}$. Copper resistance were also observed in these strains, Pontibacter korlensis-AsK09 and Bacillus-AsK15 could resist up to $250 \mu \mathrm{g} \mathrm{ml}^{-1}$, Exiguobacterium-AsK04, Bacillus megaterium-AsK08 and Exiguobacterium-CrK19 up to $500 \mu \mathrm{g}$ $\mathrm{ml}^{-1}$, Bacillus licheniformis-AsK03, AsK06, Bacillus subtilus-AsK18, CrK02, Bacillus pumilus-CrK08, CrK12, staphylococcus pasteuri-CrK14, Cellulosimicrobium cellulans-CrK16 and Bacillus cereus-CrK20 could resist up to 
$750 \mu \mathrm{g} \mathrm{ml}^{-1}$ and Acinetobacter radioresistens-AsK07 resisted up to $1000 \mu \mathrm{g} \mathrm{ml}^{-1}$. Majority of the strains (Bacillus licheniformis-AsK03, Exiguobacterium-AsK04, AsK06, Acinetobacter radioresistens-AsK07, Bacillus megateriumAsK08, CrK02, Bacillus pumilus-CrK08, Staphylococcus pasteuri-CrK14 and Exiguobacterium-CrK19) had resisted $\mathrm{MnSO}_{4}$ up to a concentration of $2000 \mu \mathrm{g} \mathrm{ml}^{-1}$ except few strains (Pontibacter korlensis-AsK09, Bacillus subtilusAsK18, CrK12, Cellulosimicrobium cellulans-CrK16, and Bacillus-AsK15, Bacillus cereus-CrK20 that showed resistance to $1250 \mathrm{\mu g} \mathrm{ml}^{-1}$ and $1000 \mathrm{\mu g} \mathrm{ml}^{-1}$, respectively). Majority of arsenic resistant strains were resisted to 2000 $\mu \mathrm{g} \mathrm{ml}^{-1}$ concentration of $\mathrm{K}_{2} \mathrm{CrO}_{4}$ except Pontibacter korlensis-AsK09 (resistant to only $500 \mu \mathrm{g} \mathrm{ml}^{-1}$ ), Acinetobacter radioresistens-AsK07 and Bacillus-AsK15 (resistant to $250 \mu \mathrm{g} \mathrm{ml}^{-1}$ ). Similarly, chromium resistant bacteria when checked on arsenate, majority of strains were resistant to $2000 \mu \mathrm{g} \mathrm{ml}^{-1}$ concentration of arsenate except Bacillus pumilus-CrK08 and Bacillus cereus-CrK20 that were resistant to only $1000 \mu \mathrm{g} \mathrm{ml}^{-1}$. Bacillus licheniformis-CrK21 was found to be resistant to all heavy metals except $\mathrm{Na}_{2} \mathrm{HAsO}_{4}$ (as shown in Table 1 and 2).

Table.1: Cross metal resistance of Arsenic resistant bacterial isolates

\begin{tabular}{|c|c|c|c|c|c|c|c|}
\hline Bacterial isolate & $\begin{array}{l}\mathrm{Hg}^{2+} \\
(\mu \mathrm{g} / \mathrm{ml})\end{array}$ & $\begin{array}{l}\mathrm{Cd}^{2+} \\
(\mu \mathrm{g} / \mathrm{ml})\end{array}$ & $\begin{array}{l}\mathrm{Cu}^{2+} \\
(\mu \mathrm{g} / \mathrm{ml})\end{array}$ & $\begin{array}{l}\mathrm{Zn}^{2+} \\
(\mu \mathrm{g} / \mathrm{ml})\end{array}$ & $\begin{array}{l}\mathrm{Mn}^{2+} \\
(\mu \mathrm{g} / \mathrm{ml})\end{array}$ & $\begin{array}{l}\mathrm{Cr}^{3+} \\
(\mu \mathrm{g} / \mathrm{ml})\end{array}$ & Level of metal resistance \\
\hline Bacillus licheniformis-AsK03 & $\mathrm{S}$ & $\mathrm{S}$ & 750 & $\mathrm{~S}$ & 2000 & 2000 & $\mathrm{Cr}^{3+}>\mathrm{Mn}^{2+}>\mathrm{Cu}^{2+}>\mathrm{Zn}^{2+}>\mathrm{Cd}^{2+}>\mathrm{Hg}^{2+}$ \\
\hline Exiguobacterium-AsK04 & $\mathrm{S}$ & $\mathrm{S}$ & 500 & $\mathrm{~S}$ & 2000 & 2000 & $\mathrm{Cr}^{3+}>\mathrm{Mn}^{2+}>\mathrm{Cu}^{2+}>\mathrm{Zn}^{2+}>\mathrm{Cd}^{2+}>\mathrm{Hg}^{2+}$ \\
\hline AsK06 & $\mathrm{S}$ & 250 & 750 & 500 & 2000 & 2000 & $\mathrm{Cr}^{3+}>\mathrm{Mn}^{2+}>\mathrm{Cu}^{2+}>\mathrm{Zn}^{2+}>\mathrm{Cd}^{2+}>\mathrm{Hg}^{2+}$ \\
\hline Acinetobacter radioresistens-AsK07 & $\mathrm{S}$ & $\mathrm{S}$ & 1000 & $\mathrm{~S}$ & 2000 & 250 & $\mathrm{Mn}^{2+}>\mathrm{Cu}^{2+}>\mathrm{Cr}^{3+}>\mathrm{Zn}^{2+}>\mathrm{Cd}^{2+}>\mathrm{Hg}^{2+}$ \\
\hline Bacillus megaterium-AsK08 & $\mathrm{S}$ & $\mathrm{S}$ & 500 & $\mathrm{~S}$ & 2000 & 2000 & $\mathrm{Cr}^{3+}>\mathrm{Mn}^{2+}>\mathrm{Cu}^{2+}>\mathrm{Zn}^{2+}>\mathrm{Cd}^{2+}>\mathrm{Hg}^{2+}$ \\
\hline Pontibacter korlensis-AsK09 & $S$ & $\mathrm{~S}$ & 250 & $\mathrm{~S}$ & 1250 & 500 & $\mathrm{Mn}^{2+}>\mathrm{Cr}^{3+}>\mathrm{Cu}^{2+}>\mathrm{Zn}^{2+}>\mathrm{Cd}^{2+}>\mathrm{Hg}^{2+}$ \\
\hline Bacillus-AsK15 & $\mathrm{S}$ & $\mathrm{S}$ & 250 & $\mathrm{~S}$ & 1000 & 250 & $\mathrm{Mn}^{2+}>\mathrm{Cr}^{3+}>\mathrm{Cu}^{2+}>\mathrm{Zn}^{2+}>\mathrm{Cd}^{2+}>\mathrm{Hg}^{2+}$ \\
\hline Bacillus subtilus-AsK18 & S & S & 750 & 250 & 1250 & 2000 & $\mathrm{Cr}^{3+}>\mathrm{Mn}^{2+}>\mathrm{Cu}^{2+}>\mathrm{Zn}^{2+}>\mathrm{Cd}^{2+}>\mathrm{Hg}^{2+}$ \\
\hline
\end{tabular}

$\mathrm{S}=$ sensitive, no growth observed

\section{Growth Pattern of a Microbial Cultures}

In majority of the strains lag phase extend up to 4 hours both in the absence and presence of heavy metals. Exponential phase was observed from 8 to 48 hours in chromium-supplemented and chromium-free medium but in arsenic supplemented and arsenic free medium, the log phase of arsenic resistant strains extended upto 8 to 72 hours.

\section{Effect of pH on Bacterial Growth}

Majority of the arsenic resistant strains preferred alkaline $\mathrm{pH} 9$ in arsenate-free medium, but after addition of $500 \mu \mathrm{g} \mathrm{ml}^{-1}$ concentration of $\mathrm{Na}_{2} \mathrm{HAsO}_{4}$ in the medium, most strains preferred neutral $\mathrm{pH} 7$ except Bacillus licheniformis-AsK03 and Bacillus subtilus-AsK18 which preferred $\mathrm{pH} 9$ on addition of arsenate. Growth of the strains in arsenic-supplemented medium was found to be better at all $\mathrm{pH}(3,5,7$ and 9) than to the growth at arsenic-free medium. At alkaline $\mathrm{pH}$, growth of strains was excelled in arsenate supplemented medium. Similarly, chromium resistant bacteria had also shown their optimum growth at alkaline $\mathrm{pH} 9$ in chromium-supplemented medium, except CrK02 which preferred $\mathrm{pH} 7$ for its optimum growth. But all the chromium resistant strains gave maximum growth at $\mathrm{pH} 7$ when chromium was absent in the medium except Exiguobacterium-CrK19 which preferred pH 9 
Table.2: Cross metal resistance of Chromium resistant bacterial isolates

\begin{tabular}{|c|c|c|c|c|c|c|c|}
\hline Bacterial isolate & $\begin{array}{c}\mathrm{Hg}^{2+} \\
(\mu \mathrm{g} / \mathrm{ml})\end{array}$ & $\begin{array}{c}\mathbf{C d}^{2+} \\
(\mu \mathrm{g} / \mathrm{ml})\end{array}$ & $\begin{array}{c}\mathrm{Cu}^{2+} \\
(\mu \mathrm{g} / \mathrm{ml})\end{array}$ & $\begin{array}{c}\mathbf{Z n}^{2+} \\
(\mu \mathrm{g} / \mathrm{ml})\end{array}$ & $\begin{array}{c}\mathbf{M n}^{2+} \\
(\mu \mathrm{g} / \mathrm{ml})\end{array}$ & $\begin{array}{c}\mathbf{A s}^{3+} \\
(\mu \mathrm{g} / \mathrm{ml})\end{array}$ & Level of metal resistance \\
\hline CrK02 & 250 & $\mathrm{~S}$ & 750 & 250 & 2000 & 2000 & $\begin{array}{c}\mathrm{As}^{3+}>\mathrm{Mn}^{2+}>\mathrm{Cu}^{2+}> \\
\mathrm{Zn}^{2+}>\mathrm{Hg}^{2+}>\mathrm{Cd}^{2+}\end{array}$ \\
\hline Bacillus pumilus-CrK08 & $S$ & 250 & 750 & 250 & 2000 & 1000 & $\begin{array}{c}\mathrm{Mn}^{2+}>\mathrm{As}^{3+}>\mathrm{Cu}^{2+}> \\
\mathrm{Zn}^{2+}>\mathrm{Cd}^{2+}>\mathrm{Hg}^{2+}\end{array}$ \\
\hline CrK12 & 750 & 1000 & 750 & 750 & 1250 & 2000 & $\begin{array}{c}\mathrm{As}^{3+}>\mathrm{Mn}^{2+}>\mathrm{Cd}^{2+}> \\
\mathrm{Cu}^{2+}>\mathrm{Zn}^{2+}>\mathrm{Hg}^{2+}\end{array}$ \\
\hline Staphylococcus pasteuri-CrK14 & 250 & $\mathrm{~S}$ & 750 & 250 & 2000 & 2000 & $\begin{array}{c}\mathrm{Mn}^{2+}>\mathrm{As}^{3+}>\mathrm{Cu}^{2+}> \\
\mathrm{Zn}^{2+}>\mathrm{Hg}^{2+}>\mathrm{Cd}^{2+} \\
\end{array}$ \\
\hline Cellulosimicrobium cellulans-CrK16 & 500 & 750 & 750 & 750 & 1250 & 2000 & $\begin{array}{c}\mathrm{As}^{3+}>\mathrm{Mn}^{2+}>\mathrm{Cu}^{2+}> \\
\mathrm{Zn}^{2+}>\mathrm{Cd}^{2+}>\mathrm{Hg}^{2+}\end{array}$ \\
\hline Exiguobacterium-CrK19 & $S$ & $S$ & 500 & 250 & 2000 & 2000 & $\begin{array}{c}\mathrm{Mn}^{2+}>\mathrm{As}^{3+}>\mathrm{Cu}^{2+}> \\
\mathrm{Zn}^{2+}>\mathrm{Cd}^{2+}>\mathrm{Hg}^{2+}\end{array}$ \\
\hline Bacillus cereus-CrK20 & 750 & 750 & 750 & 500 & 1000 & 1000 & $\begin{array}{c}\mathrm{Mn}^{2+}>\mathrm{As}^{3+}>\mathrm{Cu}^{2+}> \\
\mathrm{Cd}^{2+}>\mathrm{Hg}^{2+}>\mathrm{Zn}^{2+}\end{array}$ \\
\hline Bacillus licheniformis-CrK21 & $S$ & $\mathrm{~S}$ & $\mathrm{~S}$ & $\mathrm{~S}$ & $\mathrm{~S}$ & 2000 & $\begin{array}{c}\mathrm{As}^{3+}>\mathrm{Mn}^{2+}>\mathrm{Cu}^{2+}> \\
\mathrm{Zn}^{2+}>\mathrm{Cd}^{2+}>\mathrm{Hg}^{2+}\end{array}$ \\
\hline
\end{tabular}

$\mathrm{S}=$ sensitive, no growth observed

\section{Effect of Temperature on Bacterial Growth}

Majority of the strains gave optimum growth at $37^{\circ} \mathrm{C}$ both in presence and absence of arsenic. Nevertheless, growth was much better in arsenic free medium. All the arsenic resistant strains showed sensitivity towards both the higher and the lower temperatures both in arsenic presence and absence. However, Pontibacter korlensis-AsK09 showed optimum temperature of $28^{\circ} \mathrm{C}$ in absence of arsenic and $37^{\circ} \mathrm{C}$ in presence of arsenic. Similarly, BacillusAsK15 had optimum temperature of $28^{\circ} \mathrm{C}$ in absence of arsenic and $45^{\circ} \mathrm{C}$ in arsenic presence, while Bacillus subtilusAsK18 had optimum temperature of $45^{\circ} \mathrm{C}$ both in presence and absence of arsenic. Similarly, most chromium resistant bacteria had optimum temperature of $28^{\circ} \mathrm{C}$ in absence of chromate except for Bacillus pumilus-CrK08 and Staphylococcus pasteuri-CrK14 which had optimum temperature of $37^{\circ} \mathrm{C}$ even in absence of chromate. While $37^{\circ} \mathrm{C}$ was found to be the optimum temperature of most strains in the presence of chromate except CrK02 and Bacillus cereus-CrK20 which had optimum temperature of $45^{\circ} \mathrm{C}$.

\section{Cr (VI) Reduction at Different Initial Concentrations of $\mathrm{K}_{2} \mathrm{CrO}_{4}$}

The reduction potential of isolated strains was checked at two different initial hexavalent chromium concentrations which were $500 \mu \mathrm{g} \mathrm{ml}^{-1}$ and $1000 \mu \mathrm{g} \mathrm{ml}^{-1}$. The reduction was checked in DeLeo and Ehrlich chromate reduction medium for interval of 48 hours. The inoculum size was $100 \mu 1$. Soluble $\mathrm{Cr}$ (VI) was reduced at all the treatments with all bacterial strains, however, the reduction ability varied with the strains. The maximum reduction was done by strains CrK12, Cellulosimicrobium cellulans-CrK16 and Bacillus licheniformis-CrK21 at $500 \mu \mathrm{g} \mathrm{ml}{ }^{-1}$, whereas the lowest reduction was done by strains Bacillus pumilus-CrK08 and Exiguobacterium-CrK19 at $1000 \mu \mathrm{g}$ $\mathrm{ml}^{-1}$. The reduction of hexavalent chromium by these strains could be evidenced by lower intensity of yellow colour of the medium. At lower initial concentration of chromate, higher \% reduction was observed.

\section{Effect of Different pH on Chromium Reduction}

The effect of various $\mathrm{pH}$ was observed on chromium reduction, four different $\mathrm{pH}$ were selected which were 3, 5, 7 and 9 at an initial $\mathrm{Cr}(\mathrm{VI})$ concentration of $500 \mu \mathrm{g} \mathrm{ml}^{-1}$. After 48 hours, it was found that all the strains showed 
maximum reduction potential at $\mathrm{pH} 3$. After $\mathrm{pH} 3, \mathrm{pH} 7$ was found to be most favorable for reduction by all strains and the minimum reduction had been observed at $\mathrm{pH} 5$ by almost all strains.

\section{Effect of Different Temperatures $\left({ }^{\circ} \mathrm{C}\right)$ on Chromium Reduction}

The impact of temperature on chromium reduction was checked by providing three different temperatures $\left(28^{\circ} \mathrm{C}, 37^{\circ} \mathrm{C}\right.$ and $\left.45^{\circ} \mathrm{C}\right)$ at an initial $\mathrm{Cr}(\mathrm{VI})$ concentration of $500 \mu \mathrm{g} \mathrm{ml}^{-1}$. It was noticed, after 48 hours, that all strains follow a broad range of temperature for $\mathrm{Cr}$ (VI) reduction, but most strains inclined to grow at high temperature (45 $\left.{ }^{\circ} \mathrm{C}\right)$. However, strains $\mathrm{CrK} 02$, CrK20 and $\mathrm{CrK} 21$ had showed maximum reduction at $37^{\circ} \mathrm{C}$. For strain $\mathrm{CrK} 19$, the optimum temperature for chromium reduction was found to be $28^{\circ} \mathrm{C}$.

\section{Chromium Reduction in The Presence of Different Heavy Metals}

The impact of other heavy metals was checked on chromium reduction, two heavy metals $\mathrm{MnSO}_{4}$ and $\mathrm{Na}_{2} \mathrm{HAsO}_{4}$, at a concentration of $500 \mu \mathrm{g} \mathrm{ml}^{-1}$, were supplemented in $\mathrm{Cr}(\mathrm{VI})$ reduction medium. Harvest was made after 48 hours of incubation period. Majority of the strains showed more chromate reduction in presence of $\mathrm{MnSO}_{4}$ as compared to reduction in presence of $\mathrm{Na}_{2} \mathrm{HAsO}_{4}$. Only strain $\mathrm{CrK0} 2$ had shown maximum reduction in presence of $\mathrm{Na}_{2} \mathrm{HAsO}_{4}$. The strain that showed maximum reduction potential up to $97 \%$ was $\mathrm{CrK} 12$ and in the presence of $\mathrm{MnSO}_{4}$. By checking the heavy metal effect on chromate reduction, it was observed that in bacterial strains the aptitude of chromium resistant increased in the presence of several heavy metals especially $\mathrm{MnSO}_{4}$.

\section{Chromium Reduction in The Presence of Antibiotics}

The effect of various antibiotics was checked on chromium reduction, two antibiotics Penicillin $\left(10 \mu \mathrm{g} \mathrm{ml}^{-1}\right)$ and Chloramphenicol $\left(30 \mu \mathrm{g} \mathrm{ml}^{-1}\right)$ were supplemented in $\mathrm{Cr}(\mathrm{VI})$ reduction medium. Harvest was made after 48 hours of incubation period and it was found that chloramphenicol suppressed the reduction potential of all the strains as compared to Penicillin, and penicillin found to be enhancing the reduction potential of majority of the strains except Bacillus pumilus-CrK08 and Bacillus cereus-CrK20. The strains Bacillus pumilus-CrK08 and Bacillus cereus-CrK20 showed maximum reduction in absence of any antibiotics.

\section{Chromium Reduction at Different Time Intervals}

Chromium reduction potential was also monitored at different time intervals of 24, 48 and 72 hours. For this purpose, reduction medium was supplemented with $\mathrm{Cr}(\mathrm{VI})$ at a concentration of $500 \mu \mathrm{g} \mathrm{ml}^{-1}$ and incubated at $37^{\circ} \mathrm{C}$. Harvest was taken after regular intervals. As shown in the percentage reduction was directly proportional to the time interval. Minimum reduction had been observed after 24 hours, whereas maximum reduction potential had been observed at 72 hours. The reason behind is, due to gradual increase in cell mass with the passage of time, reduction potential also increased and had become maximum after 72 hours in all the strains. For complete reduction of chromate by bacterial strains, incubation time must be extended to more than 72 hours.

\section{Chromium Reduction in Presence of Different Media}

In the presence of minimal and enriched media, reduction of $\mathrm{Cr}(\mathrm{VI})$ was tested. Three media were amended with potassium chromate (reduction media, acetate-minimal and L-broth) at a concentration of $500 \mu \mathrm{g} \mathrm{ml}^{-1}$ and all the 
media were incubated at $37^{\circ} \mathrm{C}$. Harvest was made after 48 hours of incubation. It was found out that in acetate minimal medium, reduction potential of the bacterial strains had been suppressed and least reduction had been observed in acetate minimal medium by strain Bacillus pumilus-CrK08. Reduction potential was found to be better in enriched medium L-broth as compared to minimal medium. But maximum reduction had been observed in reduction medium itself. Strain CrK02 had shown $48 \%$ reduction in L-broth, which was the maximum reduction observed in case of Lbroth. Strain CrK14 had shown $82 \%$ reduction in reduction medium which was the highest percentage reduction in all the three media.

\section{Genetic Characterization of Arsenic and Chromium Resistant Bacteria 16S rRNA Sequencing of the Strains}

All these arsenic and chromium resistant strains, AsK03, AsK04, AsK07, AsK08, AsK09, AsK15, AsK18, CrK08, CrK14, CrK16, CrK19, CrK20 and CrK21 were identified by the sequencing of 16S rRNA gene. Seven strains exhibited homology closer with genus of Bacillus. The highest homology had been observed with Bacillus licheniformis (AsK03 and CrK21) and Exiguobacterium sp. (AsK04 and CrK19), whereas others isolates were found to be homologous to Acinetobacter radioresistens (AsK07), Bacillus megaterium (AsK08), Pontibacter korlensis (AsK09), Bacillus sp. (AsK15), Bacillus subtilus (AsK18), Bacillus pumilus (CrK08), Staphylococcus pasteuri (CrK14), Cellulosimicrobium cellulans (CrK16) and Bacillus cereus (CrK20). These isolates were almost 99\% similar to the Blast database reference sequences, except AsK09 that showed 97\% homology with Pontibacter korlensis.

\section{Discussion}

The most commonly occurring microorganisms are bacteria, yeast, or protozoa, which may minimize or fully remove water or soil pollutants. Bioremediation is a process whereby organic wastes are biologically despoiled under restricted circumstances to an inoffensive state. Microbial bioremediation can act in two ways. Microorganisms can change a compound to another form that is not hazardous. This chemical change is called biotransformation, or they can chemically break up the noxious compound into smaller components. This is called biodegradation. As the pace of industrialization and urbanization has increased in Pakistan over the past two decades, the environmental pollution has increased because of unplanned and unprocessed industrial waste disposal. The main contributors in such pollution are the leather and steel industry because of water-borne components of extremely toxic nature such as As (III), Cr (VI) and Cd (II) in untreated industrial wastes. In Pakistan, the public still has very little awareness of the pollution, its dangers, and the need for remedy. There are several micro-organisms in industrial waste waters in all these industrial areas which seem to thrive on this water derived from industrial wastewater components and have become toxic to pollutants (Muneer, 2005). In Kasur, tannery effluents are released in open ground, making the atmosphere totally smelly and air inexpressible. Kasur is $54 \mathrm{~km}$ south-east of Lahore and is renowned for its tanning industry. For development of leather, it is second to Karachi. The highly contaminated waste from tanneries has a significant impact both on the environment and on Kasur people (Muneer, 2005). Salt tanneries, the primary effluent stream in the leather processing industry, are created by removing excess salt-charged hides and skin in freshwater. The high salinity (1$10 \% \mathrm{NaCl}$ by wt) present in this waste stream impedes biological processing (Dhanehwar, 1990; Sivaprakasam, 2008). Electroplating, fungicides, tanning leather, inhibitors of corrosion and metallurgy are among the most common 
historical applications (Palmer and Wittbrodt, 1991). In many industrial processes, hexavalent chromium $\mathrm{Cr}$ (VI) ionic forms, such as, $\mathrm{HCrO}_{4}{ }^{-}, \mathrm{CrO}_{4}{ }^{2-}$, and $\mathrm{Cr}_{2} \mathrm{O}_{7}{ }^{2-}$ are used universally, like photographic sensitizer manufacturing, wood processing, metal finishing, textile processing, paints, dyes, ceramics and pigments manufacturing, chrome plating, chrome leather tanning and others. The disposal of these high toxic chromate wastes causes anthropogenic pollution of pristine ecosystems (Desai, 2008). Arsenic is more harmful than chromium and inevitably is a major global environmental toxicant affecting human health. In the world millions of people suffer from the use of Arseniccontaminated groundwater with skin infections, tumors, or other associated conditions. Many have died and in many countries hundreds of millions are at risk (Chakraborti, 2003). The comparative assessment heavy metal profile of chromimum resistant bacteria is showed in Figure 1 and arsenic resistance bacteria is in Figure 2. Highest homology was observed with Bacillus licheniformis (AsK03 and CrK21) and Exiguobacterium sp. (AsK04 and CrK19), whereas others isolates were found to be homologous to Acinetobacter radioresistens (AsK07), Bacillus megaterium (AsK08), Pontibacter korlensis (AsK09), Bacillus sp. (AsK15), Bacillus subtilus (AsK18), Bacillus pumilus (CrK08), Staphylococcus pasteuri (CrK14), Cellulosimicrobium cellulans (CrK16) and Bacillus cereus (CrK20). All these strains showed high resistance against As (VI) and Cr (VI). Nine different antibiotic (Ampicillin (Amp) - $25 \mu \mathrm{g} / \mathrm{ml}$, Oxytetracyclin (T) - $30 \mu \mathrm{g} / \mathrm{ml}$, Erythromycin (E) - $15 \mu \mathrm{g} / \mathrm{ml}$, Penicillin (P) - $10 \mu \mathrm{g} / \mathrm{ml}$, Chloramphenicol (C) - 300 $\mu \mathrm{g} / \mathrm{ml}$, Carbenicillin (CAR) - $100 \mu \mathrm{g} / \mathrm{ml}$, Cefadroxil (CF) - $30 \mu \mathrm{g} / \mathrm{ml}$, Cyprofloxacin (CPF) - $30 \mu \mathrm{g} / \mathrm{ml}$, and Doxycillin (D) $-30 \mu \mathrm{g} / \mathrm{ml}$ ) impregnated discs were selected to check bacterial antibiotic resistance. Majority of the strains were resistant to ampicillin, oxytetracycline, erythromycin, penicillin, chloramphenicol and carbenicillin. Overall, strains AsK04, CrK19 and CrK21 exhibited sensitivity towards every antibiotic. The remaining strains provided variable results. Resistance towards ampicillin and chloramphenicol was also exhibited by the bacterial strains isolated by Faisal and Hasnain (2004). None of the strain could resist cefaclor, ciprofloxacin and doxycillin. For optimum temperature, $\mathrm{pH}$, and growth curves, the bacterial isolates were characterized. The number and efficiency of microorganisms in the bioremediation of toxic metal waste can be increased by optimizing the growth conditions (Haq and Shakoori, 2000). In the presence and absence of arsenate all arsenic resistant bacterial isolates displayed

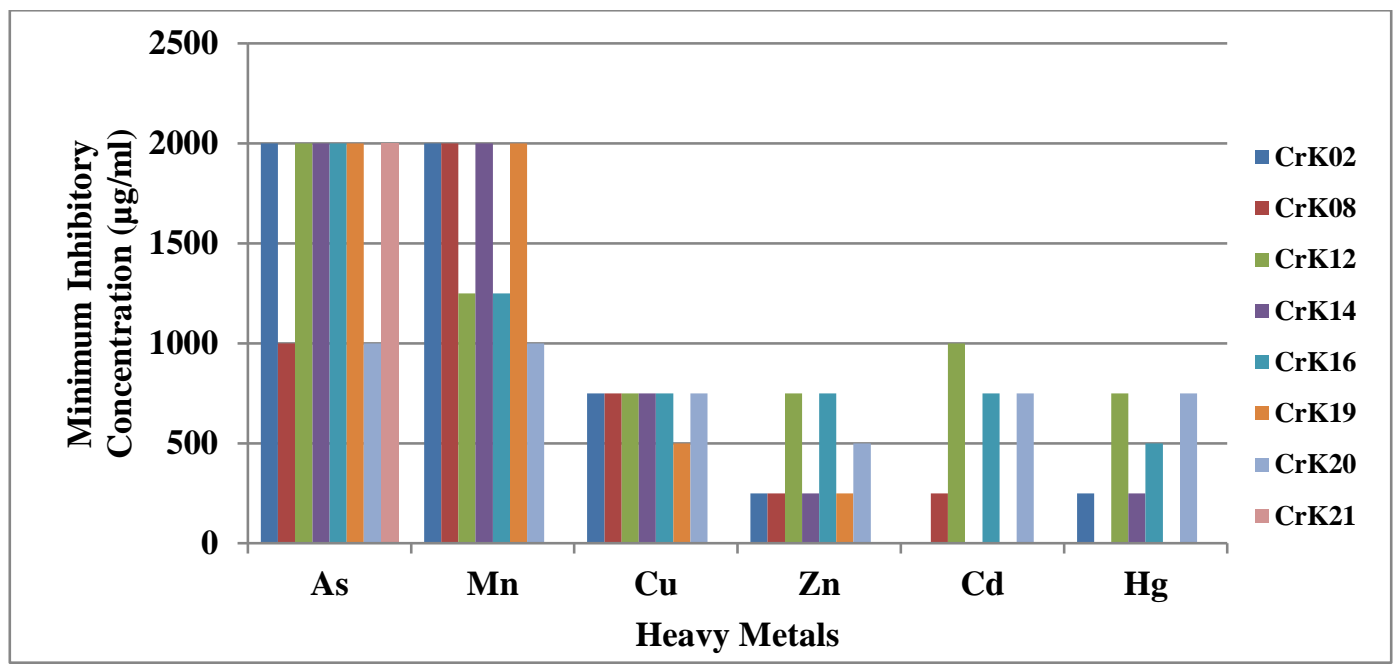

Figure 1: Comparative study of heavy metal profiling of Chromate resistant bacterial isolates. 


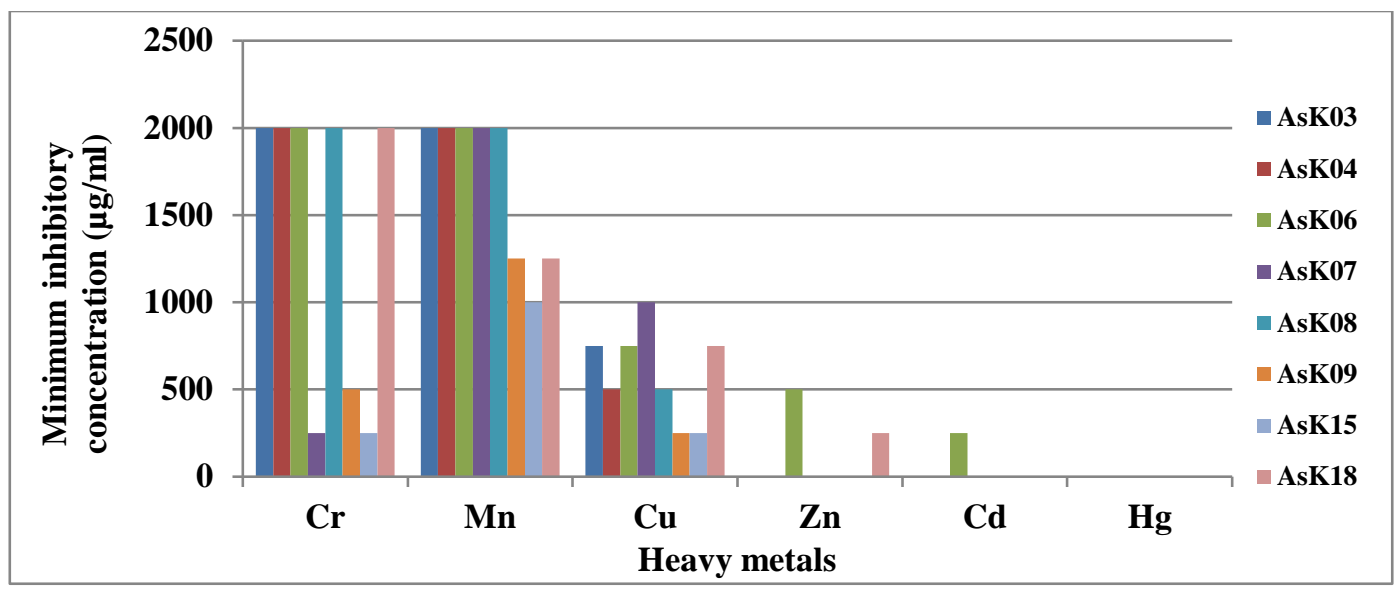

Figure 2: Comparative study of heavy metal profiling of Arsenic resistant bacterial isolates.

maximum growth of $37^{\circ} \mathrm{C}$, whereas majority of chromium resistant bacteria, in the absence of chromate, showed maximum growth at $28^{\circ} \mathrm{C}$, but in its presence, maximum growth observed at $37^{\circ} \mathrm{C}$. This is due to the optimum functioning of the enzymes at this temperature, so metabolic processes and development take place at their best. Also, the optimum $\mathrm{pH}$ was optimized for bacterial isolates. In the current study, the ability of bacterial isolates to reduce chromate was measured and all the bacterial isolates were found to reduce chromium in the culture medium very efficiently. Microorganisms' capacity to reduce chromium was calculated by adding two separate initial concentrations of chromium (500 and $1000 \mu \mathrm{g} \mathrm{ml}^{-1}$ ) to the DeLeo and Ehrlich (1994) medium. It was seen that as the concentration of chromate in the culture medium was increased, the percentage reduction decreased. This trend could be attributed to the fact that chromate in high concentration inhibits cellular growth as evident by a decrease in the biomass. The maximum reduction for all the bacterial isolates occurred with an arsenic concentration of $500 \mu \mathrm{g} \mathrm{ml}^{-1}$. The concentration of chromium in the supernatants decreased with the passage of time, showing that the concentration of chromium in the culture medium decreased. This decrease occurred due to uptake of chromium by the bacterial isolates from the medium. The maximum reduction potential, reflected by the maximum removal of chromium from the culture medium, was exhibited by bacterial isolates CrK12 and CrK16. Results indicated the high arsenate and chromate detoxification efficiency of the arsenic and chromium resistant bacteria. This study revealed that the metal reduction ability of these bacterial isolates is appreciable which can be exploited for the arsenate and chromate removal from toxic industrial waste and for the bioremediation of metal polluted sites.

\section{References}

Abdrashitova, S. A., Abdullina, G. G. and Ilialetdinov, A. N. 1986. Role of arsenites in lipid peroxidation in Pseudomonas putida cells oxidizing arsenite. Mikrobiologiya, 55: 212-216.

Abernathy, C. O., Liu, Y., Longfellow, D., Aposhia, H. V., Beck, B., Fowler, B., Goyer, R., Menzer, R., Rossman, T., Thompson, C. \& Waalkes, M. 1999. Arsenic, health effects, mechanisms of actions, and research issues. Environmental Health Perspectives, 107:593-597. 
Abernathy, C. O., Thomas, D. J. \& Calderon, R. L. 2003. Health effects and risk assessment of arsenic. Journal of Nutrition, 133: 1536-1538.

Abou-Shanab, R. A., Ghozlan, H., Ghanem, K. \& Moawad, H. 2005. Behavior of bacterial populations isolated from rhizosphere of Diplachne fusca dominant in industrial sites. World Journal of Microbiology and Biotechnology, 21: 1095-1101.

Ackerley, D. F., Gonzalez, C. F., Park, C. H., Blake, R., Keyhan, M. \& Matin, A. 2004. Chromate-reducing properties of soluble flavoproteins from Pseudomonas putida and Escherichia coli. Applied and Environmental Microbiology, 70: 873-882.

Ackerley, D. F., Gonzalez, C. H., Blake, R., Keyhan, M. \& Matin, A. 2004. Mechanism of chromate reduction by the Escherichia coli protein, NfsA, and the role of different chromate reductases in minimizing oxidative stress during chromate reduction. Environmental Microbiology, 6(8): 851-860.

Ackerley, D. F., Gonzalez, C. F., Keyhan, M., Blake, R. \& Matin, A. 2005. Biomolecular strategy to decrease chromate toxicity to remediating bacteria, p. 259-268. In M. de Conceicao Cunha \& C. A. Brebbia (eds.), Water resources management III. WIT Press, Wessex, England.

Ackerley, D. F., Barak, Y., Lynch, S. V., Curtin, J. \& Matin, A. 2006. Effect of chromate stress on Escherichia coli K-12. Journal of Bacteriology, 188(9): 3371-3381.

Adeniiji, A. 2004. Bioremediation of arsenic, chromium, lead and mercury. USEPA, Washington, D.C., www.cluin.org.

Aguilera, S., Aguilar, M. E., Chàvez, M. P., López-Meza, J. E., Pedraza-Reyes, M., Campos-Garcĺa, J. \& Cervantes, C. 2004. Essential residues in the chromate transporter ChrA of Pseudomonas aeruginosa. FEMS Microbiology Letters, 232: 107-112.

Ahmad, S., Kitchin, K. T. \& Cullen, W. R. 2000. Arsenic species that cause release of iron from ferritin and generation of activated oxygen. Archives of Biochemistry and Biophysics, 382: 195-202.

Ahmann, D., Krumholz, L. R., Hemond, H. F., Lovely, D. R. \& Morel, F. M. M. 1997. Microbial mobilization of arsenic from sediments of the Aberjona watershed. Environmental Science \& Technology, 31: 2923-2930.

Ahsan, H., Perrin, M., Rahman, A., Parvez, F., Stute, M. and Zheng, Y., Milton, A. H., Brandt-Rauf, P., Van-Geen, A. \& Graziano, J. 2000. Associations between drinking water and urinary arsenic levels and skin lesions in Bangladesh. Journal of Occupational and Environmental Medicine, 42: 1195-1201.

Aiyar, J., Buerkovitis, H. J., Floyd, R. A. \& Borges, K. 1991. Reaction of chromium (VI) with glutathione or with hydrogen peroxide, Identification of reactive intermediates and their role in chromium (VI) - induced DNA damage. Environmental Health Perspectives, 92: 53-62.

Altschul, S. F., Madden, T. L., Schaffer, A. A., Zhang, J., Zhang, Z. \& Miller W. 1997. Gapped BLAST and PSIBLAST, a new generation of protein database search programs. Nucleic Acids Research, 25: 3389-402.

Alvarez, A. H., Moreno-Sánchez, R. \& Cervantes, C. 1999. Chromate efflux by means of the ChrA chromate resistance protein from Pseudomonas aeruginosa. Journal of Bacteriology, 181: 7398-7400. 